\title{
Immunological abnormalities in the syndrome of poliomyelitis-like illness associated with acute bronchial asthma (Hopkins's syndrome)
}

\author{
J I MANSON AND Y H THONG
}

Department of Neurology, Adelaide Children's Hospital, and Department of Paediatrics, University of Adelaide, Australia

SUMMARY In recent years an unusual syndrome of poliomyelitis-like illness, associated with acute bronchial asthma, has been reported from different parts of the world. A further 3 cases are described in this paper. Although the condition resembles poliomyelitis in most respects, particularly with regard to the severe permanent residual weakness usually observed, consistent evidence of a viral aetiology has not been forthcoming. Tests of immune function suggested the presence of varying degrees of nonspecific immune deficiency in our 3 patients, but evidence of viral invasion was inconclusive. It is suggested that a combination of immune deficiency with the stress of the acute asthma attack rendered the patients susceptible to invasion of the anterior horn cells by a viral agent, which may have been of external origin, or may have existed in a latent form within the host.

In 1974 Hopkins and Shield described 10 children who had a poliomyelitis-like illness 4 to 7 days after an acute asthma attack. $^{1-2}$ The illness was characterised by the rapid evolution over a period of several days of a severe and extensive lower motor neurone paralysis, affecting only one limb in most cases, although in 2 patients patchy weakness of wider distribution was described. The cerebrospinal fluid showed a lymphocyte or neutrophil pleocytosis in all cases but one. The cerebrospinal fluid protein was raised in half the patients, and some degree of neck or spine stiffness was present in half of them. All patients had been previously fully immunised against poliomyelitis with Sabin vaccine in infancy. Extensive virological studies were performed on Hopkins's patients. Serial blood poliovirus antibody estimations showed no rise in titre in the 7 cases tested. Adenovirus type 3 was isolated from the stool of one patient, and echo virus type 18 from the stool of another. The stools of 9 patients were investigated for virus. Polio virus was not detected in any patient. Electrophysiological studies were performed on 2 patients and were noncontributory. In only one patient was there significant generalised

Department of Neurology, Adelaide Children's Hospital

J I MANSON, director

Department of Paediatrics, University of Adelaide

Y H THONG, senior lecturer hypoxia. Although a wide range of drugs had been given to the patients during the asthma attacks, no single drug was common to all 10 patients. Corticosteroids had been given to only 5 of them. A feature of the syndrome was the severe degree of permanent residual weakness in the affected muscles.

Danta described a case of a similar syndrome in an 8-year-old girl. ${ }^{3}$ Five days after an acute asthma attack the girl developed almost complete paralysis of the left upper limb muscles and recovery was incomplete.

Ilett et al. ${ }^{4}$ reported 2 further cases of the same syndrome, with severe permanent lower motor neurone weakness occurring in the left arm of each patient, developing 18 and 7 days respectively after an acute asthma attack. It was observed that the left arm in each case was the site of intravenous therapy, and they compared this with clinical paralytic poliomyelitis, which has been known selectively to affect limbs which have been the site of injections. Another case with involvement of the right arm has recently been reported from the USA. ${ }^{5}$

The possibility that immunodeficiency may play a role in the aetiology of this syndrome is suggested by several independent observations. Asthmatics as a group have been found to have reduced immunological responses compared with normal subjects. ${ }^{6}$ Also, patients with specific immunodeficiencies, such 
as selective $\operatorname{Ig} \mathrm{A}$ deficiency, have an increased predilection to allergy and bronchial asthma. ${ }^{723}$ Furthermore, immunodeficient subjects have developed poliomyelitis after immunisation with oral polio vaccine. ${ }^{8}$

Three patients with a syndrome identical with that described by Hopkins have been seen at this hospital during the last 5 years. Their details are presented below, and their clinical and virological aspects are summarised in Tables 1 and 2.

\section{Case 1, born 24 November 1972}

This child was a known asthmatic who was admitted with status asthmaticus on 11 February 1974 . He was treated with intravenous aminophylline, salbutamol, hydrocortisone, and intravenous fluids, and his condition improved within 48 hours. On day 5 the child developed severe and extensive lower motor neurone paralysis of all muscle groups of both upper limbs, with subsequent gross wasting, areflexia, and flaccidity. The child was noted to have active deep tendon reflexes and bilateral Babinski responses in both lower limbs. Sensory examination was negative. Complete blood count examination on the day of admission showed a haemoglobin of $13 \cdot 2$ $\mathrm{g} / \mathrm{dl}$, with normal red cell indices. Total white blood count was $16.6 \times 10^{9} / 1$, with a differential count of $96 \%$ neutrophils, $1 \%$ lymphocytes, and $3 \%$ monocytes. On day 7 after admission the haemoglobin was $14.0 \mathrm{~g} / \mathrm{dl}$, with normal red cell indices. The total white blood count was $6 \cdot 1 \times 10^{9} / 1$, with $32 \%$ neutrophils, $5 \%$ eosinophils, $48 \%$ lymphocytes, $14 \%$ monocytes, $1 \%$ plasma cells, and a few myelocytes. There was an occasional atypical lymphocyte present. A myelogram was negative; CSF contained 13 lymphocytes/ $\mu 1$; CSF protein was $0 \cdot 13 \mathrm{~g} / \mathrm{l}$, CSF and faeces cultures were negative for viruses; however, varicella virus was obtained from the throat, although the child had no clinical features of varicella, and there was no rise in the titre of varicella antibody in the serum. Serological specimens showed no significant rise in titre to a wide range of viruses, including Mycoplasma. Polio virus titres were not examined at the time, but subsequent examination in 1979 was negative for poliovirus types 2 and 3, and positive to a titre of 1 in 24 for poliovirus type 1. A limited examination of cellular and humoral immune functions was performed one week after the acute phase. Serum IgG was $3.9 \mathrm{~g} / \mathrm{l}$, $\operatorname{IgA} 0.23 \mathrm{~g} / \mathrm{l}, \operatorname{IgM} 1.35 \mathrm{~g} / \mathrm{l}$, and $\operatorname{IgE} 3550 \mathrm{IU} / \mathrm{ml}$. Serum pneumococcal capsular antibody titre was less than 10, rising to 80 after stimulation. Serum tetanus antitoxin haemagglutination titre was $1: 128$. Lymphocyte transformation with phytohaemagglutinin was 7500 counts/min (normal range 5900 to 49 400). Skin tests for delayed hypersensitivity, using monilia and streptokinase, were negative. Serial electromyographic (EMG) studies confirmed an extensive process of severe lower motor neurone denervation in both upper limbs affecting all segments from C5 to $\mathrm{T} 1$, with absent or greatly reduced interference patterns in all the muscles tested, and numerous fibrillations and positive

Table 1 Clinical aspects

\begin{tabular}{|c|c|c|c|c|c|c|}
\hline Case & Age (years) & Clinical features & Day of onset & $C S F$ & $E M G$ & Recovery \\
\hline 1 & $2 \cdot 3$ & $\begin{array}{l}\text { Lower motor neurone } \\
\text { paralysis both arms } \\
\text { (C5-T1) }\end{array}$ & 5 & 13 lymphocytes, protein 13 & $\begin{array}{l}\text { Complete denervation } \\
\mathrm{L} \text { deltoid }\end{array}$ & Poor \\
\hline 2 & $11 \cdot 4$ & $\begin{array}{l}\text { Lower motor neurone } \\
\text { paralysis } \\
\text { L arm, L leg (patchy } \\
\text { distribution) }\end{array}$ & 4 & $\begin{array}{l}4 \text { RBC, } 2 \text { lymphocytes, } \\
1 \text { polymorph. Protein } 70\end{array}$ & $\begin{array}{l}\text { Partial denervation } \\
\quad \mathbf{L} \text { triceps, } \mathbf{L} \text { tibialis anterior }\end{array}$ & Moderate \\
\hline 3 & $4 \cdot 2$ & $\begin{array}{l}\text { Lower motor neurone } \\
\text { paralysis } L \text { arm } \\
\text { (C5-T1) }\end{array}$ & 5 & Normal (3 months later) & $\begin{array}{l}\text { Complete denervation } \\
\text { L biceps, } L \text { triceps; } \\
\text { Partial denervation } \\
\text { L 1st dorsal interosseus }\end{array}$ & Poor \\
\hline
\end{tabular}

Table 2 Virological aspects

\begin{tabular}{|c|c|c|c|c|}
\hline Case & Viral cultures & Serology & Immunisation status & Polio antibodies (1979) \\
\hline 1 & $\begin{array}{l}\text { Throat, Varicella. } \\
\text { CSF, negative. } \\
\text { Faeces, negative }\end{array}$ & Negative & Full Sabin immunisation & $\begin{array}{l}\text { Type } 11: 24 \\
\text { Type } 2 \text { Negative } \\
\text { Type } 3 \text { Negative }\end{array}$ \\
\hline 2 & Throat, negative & $\begin{array}{l}\text { Static increase in Cocksackie B1 } \\
1: 512\end{array}$ & Full Sabin immunisation & 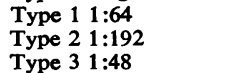 \\
\hline 3 & Not done & Not done & Full Sabin immunisation & $\begin{array}{ll}\text { Type } 1 & 1: 256 \\
\text { Type } 2 & 1: 128 \\
\text { Type } 3 & 1: 32\end{array}$ \\
\hline
\end{tabular}


sharp waves. No spontaneous fasciculations were recorded. Voluntary interference patterns in the right biceps contained sparsely distributed polyphasic potentials of up to $12 \mathrm{mV}$ amplitude, and up to 15 to 20 milliseconds' duration. Sensory action potentials in the left median nerve had a latency of $2 \mathrm{~ms}$, and an amplitude of $25 \mu \mathrm{V}$. Ulnar and median nerve motor conduction could not be estimated due to the severity of the denervation of the hand musculature.

The child has subsequently made very little recovery. In December 1978 he had gross bilateral paralysis of all muscle groups in both upper limbs (Fig. 1), the only residual function being some partial flexion of the fingers of the right hand and some slight biceps function in the right arm. Subsequent inquiries showed that the child had been fully immunised against poliomyelitis in infancy. Over the years he has been prone to frequent minor upper respiratory illnesses, with intermittent exacerbation of his asthma, which appears to be improving with the passage of time.

\section{Case 2, born 2 July 1966}

This 11-year-old asthmatic child had been fully immunised against polio in infancy with Sabin vaccine. He was admitted with a severe asthma attack on 22 June 1974. His condition improved

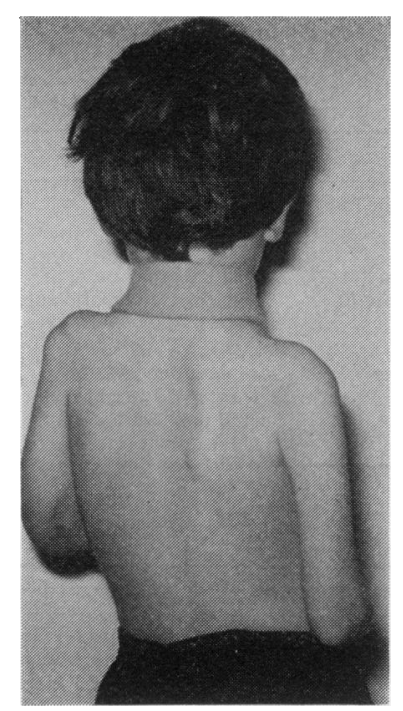

Fig. 1 Case 1, 5 years after the acute attack. Note wasting of the spinati and de!toids. The child is wearing a sling because of a recent pathological fracture of the left humerus. after treatment with intravenous hydrocortisone and he was discharged on 27 June. However, he returned to hospital on 1 July complaining of weakness and pain in the left lower limb, which he had noticed initially on day 4, after the onset of his recent asthma attack. On day 5 after the initial admission he had noted some weakness of his left arm, which he had attributed to the intravenous injection administered in the left arm. On examination he had gross weakness of the left triceps, and less severe weakness of deltoid, biceps and wrist extensors, with biceps wasting. There was gross weakness of the left hip flexors, extensors, and quadriceps; the more distal muscle groups in the left lower limb appeared relatively preserved. There was pronounced depression of deep tendon reflexes in the left arm and left leg. Sensory examination was normal. The ulnar and median nerves in the left arm, and the medial and lateral popliteal nerves in the left leg were all tender to palpation. There was pronounced limitation of straight leg raising, especially of the left lower limb. Complete blood count on 22 June gave a haemoglobin of $13.0 \mathrm{~g} / \mathrm{dl}$, with normal red cell indices. White blood count was $17.3 \times 10^{9} / 1$, with $75 \%$ neutrophils, $18 \%$ lymphocytes, $7 \%$ monocytes, and a few myelocytes. A repeat blood count on 2 July showed a fall in the WBC to $7.6 \times 10^{9} / 1$, with $46 \%$ neutrophils, $4 \%$ eosinophils, $1 \%$ basophils, $39 \%$ lymphocytes, $8 \%$ monocytes, and $2 \%$ plasma cells. CSF examination showed 4 red cells $/ \mu l, 2$ lymphocytes $/ \mu \mathrm{l}$, and 1 polymorph $/ \mu \mathrm{l}$. CSF protein was $0 \cdot 70 \mathrm{~g} / \mathrm{l}$, CSF sugar normal. Viral cultures of throat, faeces, and CSF were negative. Serological tests showed a constant increase in the titre to Cocksackie B1 at a level of 1 in 512 on 9 July and 19 July, but were otherwise negative. Serological tests for polio antibodies were not done at the time, but when tested for in 1979 there was a positive titre of 1 in 64 to poliovirus type 1,1 in 192 to poliovirus type 2 , and 1 in 48 to poliovirus type 3 . Serum IgG was $10 \cdot 25 \mathrm{~g} / \mathrm{l}, \operatorname{IgA} 1 \cdot 15 \mathrm{~g} / \mathrm{l}$, and $\operatorname{IgM} 2 \cdot 18 \mathrm{~g} / \mathrm{l}$. Tetanus antitoxin haemagglutination titre was $1: 128$. EMG examination showed normal motor nerve conduction velocities of 50 metres/second and 68 metres/second in the left ulnar and left peroneal nerves respectively. Concentric needle sampling of the left triceps, left abductor digiti minimi, and left tibialis anterior, showed spontaneous positive sharp waves and fibrillation potentials at rest. Interference patterns consisted of sparsely distributed polyphasic units of $2 \mathrm{mV}$ amplitude with very low voltage activity intervening, in all 3 muscles sampled.

At follow-up in December 1978 he had a severe residual weakness of the left lower limb with wasting of the gluteals and thigh muscles (Fig. 2). The left upper limb showed only slight residual 


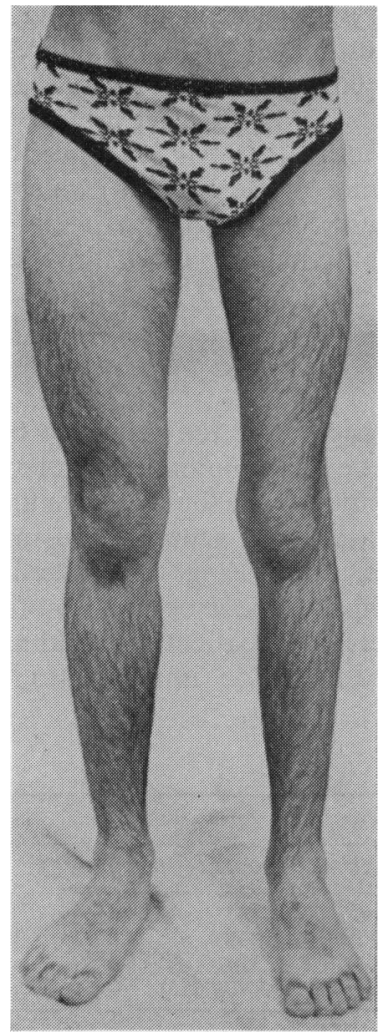

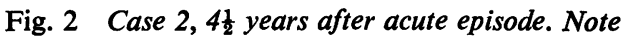
wasting of left thigh musculature. There is also some mild gastrocnemius wasting.

weakness and slight wasting of the triceps, biceps, and forearm flexors. Some fasciculations were observed in the left triceps.

\section{Case 3, born 30 June 1972}

This child had had recurrent asthma attacks before his admission to a rural district hospital in August 1976 with a very severe asthma attack. He required intravenous corticosteroids, intubation, and assisted ventilation. Five days after cessation of assisted ventilation a paralysed left arm was noted. Examination by the local doctor showed a severe paralysis of the left shoulder and elbow. When seen in the neurology clinic in November there was complete loss of all voluntary movements of the left shoulder and elbow, with gross wasting and weakness of all muscles in the C5, C6, and $\mathrm{C7}$ distribution, including the rhomboids, the serratus anterior, and supraspinatus and infraspinatus muscles. There was some weak action of the intrinsic muscles of the left hand. The biceps, triceps, and supinator jerks were absent in the left upper limb. There was no sensory loss. EMG showed normal left median and ulnar nerve conduction velocities of 60 metres/second and 55 metres/second, respectively. Sensory conduction along the left median nerve showed a peak latency of $1.8 \mathrm{~ms}$ and a response amplitude of $20 \mathrm{mV}$. EMG sampling of the left biceps, triceps, and first dorsal interosseus, showed prominent fibrillation potentials and positive sharp waves in all 3 muscles. No voluntary units could be recorded from the biceps or triceps, but some were obtained from the first dorsal interosseus. Acute viral studies were not obtained because of the long time lapse between the acute illness and the presentation at this hospital. The CSF was examined in November 1976 and was completely normal. Immunological studies were not performed at that time. The child had had full Sabin polio immunisation in infancy. The following serum poliovirus titres were obtained: poliovirus type 1 was positive to a titre of 1 in 256; poliovirus type 2 was positive to a titre of 1 in 128; and poliovirus type 3 was positive to a titre of 1 in 32 .

At follow-up in December 1978 he had a flail left shoulder and elbow (Fig. 3), with moderate weakness of dorsiflexion of the left wrist and fingers, and moderate weakness of the intrinsic muscles of the left hand. There was moderate strength in the long

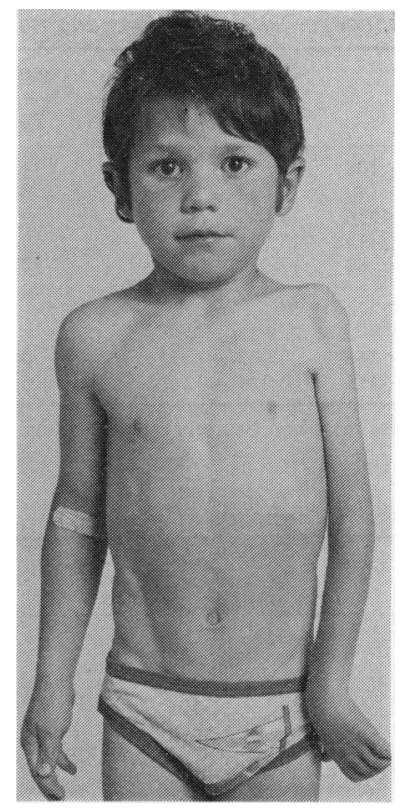

Fig. 3 Case 3, 2 years after acute episode. Note extensive wasting of left upper arm musculature. 


\section{Manson and Thong}

flexors of the wrist and fingers. There had been no significant recovery during this 2-year period of observation.

In 1978 the 3 children described were recalled, and blood was drawn for immunological studies. The methods used are detailed below.

\section{Methods}

Serum immunoglobulin (IgA, IgG, IgM) and complement $(\mathrm{C} 3, \mathrm{C} 4)$ concentrations were measured by radial immunodiffusion, using commercial plates (Behringwer, W. Germany). Serum IgE was measured by radioimmunoassay (Pharmacia, Sweden). Total haemolytic complement activity (CH50) was estimated by the lysis of sheep red blood cells. ${ }^{9}$ Lymphocytes and neutrophils were purified from peripheral blood by a one-step gradient centrifugation procedure. ${ }^{10}$ Lymphocyte transformation was examined, using a microtechnique. ${ }^{24} \mathrm{~T}$-cells were estimated as the percentage bearing E-rosettes.11 B-cells were estimated by immunoflorescence, using goat antihuman Ig. ${ }^{12}$ Neutrophil chemotaxis was measured by the agarose technique. ${ }^{21}$ Neutrophil quantitative iodination was examined by a microassay procedure. ${ }^{13}$ Bactericidal capacity was tested by the killing of Staphylococcus aureus. ${ }^{14}$ Fungicidal capacity was tested by the killing of Torulopsis glabrata. ${ }^{15}$

\section{Results}

Tables 3, 4, and 5 give the results of the battery of humoral and cellular immunological tests performed on blood samples from these 3 patients. The results show that Case 1 had a number of immunological abnormalities, comprising raised serum $\operatorname{IgM}$ and IgE levels, impaired neutrophil chemotaxis, and low T-cell numbers. This patient also had an inadequate serological response to immunisation with Sabin

Table 3 Serum immunoglobulins and complement activity (1978)

\begin{tabular}{|c|c|c|c|c|c|c|c|c|c|}
\hline \multirow[t]{2}{*}{ Case } & \multirow[t]{2}{*}{ Age (years) } & \multirow[t]{2}{*}{ Sex } & \multicolumn{4}{|c|}{ Serum immunoglobulins } & \multicolumn{3}{|c|}{ Serum complement } \\
\hline & & & $G(g / l)$ & $A(g / l)$ & $M(g / l)$ & $E(I U / m l)$ & CHSO (U/ & $C 3(\mathrm{~g} / \mathrm{l})$ & $C 4(\mathrm{~g} / \mathrm{l})$ \\
\hline $\begin{array}{l}1 \\
2 \\
3 \\
\text { Normal range }\end{array}$ & $\begin{array}{r}8 \\
16 \\
6\end{array}$ & $\begin{array}{l}\mathbf{M} \\
\mathbf{M} \\
\mathbf{M}\end{array}$ & $\begin{array}{l}9 \cdot 1 \\
9 \cdot 1 \\
10 \cdot 9 \\
5 \cdot 6-14 \cdot 9\end{array}$ & $\begin{array}{l}0 \cdot 60 \\
0 \cdot 87 \\
1 \cdot 90 \\
0 \cdot 5-2 \cdot 3\end{array}$ & $\begin{array}{l}1 \cdot 42 \\
2 \cdot 16 \\
2 \cdot 10 \\
0 \cdot 3-1 \cdot 3\end{array}$ & $\begin{array}{l}1546 \\
613 \\
902 \\
64-392\end{array}$ & $\begin{array}{l}167 \\
85 \\
124 \\
90-165\end{array}$ & $\begin{array}{l}1 \cdot 60 \\
0 \cdot 72 \\
0 \cdot 68 \\
0 \cdot 8-1 \cdot 2\end{array}$ & $\begin{array}{l}0.30 \\
0.25 \\
0.23 \\
0.2-0.4\end{array}$ \\
\hline
\end{tabular}

Table 4 Lymphocyte subpopulations and mitogen-induced transformation (1978)

\begin{tabular}{|c|c|c|c|c|c|c|}
\hline \multirow[t]{2}{*}{ Cases } & \multirow[t]{2}{*}{ Resting } & \multicolumn{3}{|c|}{${ }^{3}$ H-thymidine uptake (counts/min $\pm S D$ ) } & \multirow[t]{2}{*}{$T$-cells $(\%)$} & \multirow[t]{2}{*}{ B-cells $(\%)$} \\
\hline & & Phytohaemagglutinin & Pokeweed mitogen & Concanavalin $A$ & & \\
\hline 1 & $\begin{array}{r}606 \pm 108 \\
1345 \pm 170 \\
808 \pm 356 \\
162 \pm 13 \\
664 \pm 84\end{array}$ & $\begin{array}{l}12922 \pm 2155 \\
12914 \pm 1583 \\
19028 \pm 780 \\
15991 \pm 965 \\
12538 \pm 916\end{array}$ & $\begin{array}{r}11798 \pm 2032 \\
4867 \pm 507 \\
9340 \pm \\
9240 \pm \\
8754 \pm \\
\pm\end{array}$ & $\begin{array}{r}24523 \pm 2507 \\
8116 \pm 1356 \\
17760 \pm 1154 \\
26670 \pm 1862 \\
10146 \pm 1288\end{array}$ & $\begin{array}{l}38 \\
23 \\
25 \\
32 \\
59\end{array}$ & $\begin{array}{r}12 \\
13 \\
10 \\
9 \\
12\end{array}$ \\
\hline \multicolumn{7}{|c|}{$\begin{array}{l}\text { Controls }(n=22) \\
\text { Mean } \pm\end{array}$} \\
\hline $\begin{array}{c}\text { SD } \\
\text { Range }\end{array}$ & $\begin{array}{l}512 \pm 256 \\
167-995\end{array}$ & $\begin{array}{l}20003 \pm 5524 \\
12228-32625\end{array}$ & $\begin{array}{l}9485 \pm 2408 \\
5853-14526\end{array}$ & $\begin{array}{c}16269 \pm 5669 \\
9529-33600\end{array}$ & $\begin{array}{l}61 \pm 5 \\
52-70\end{array}$ & $\begin{array}{r}10 \pm 1 \\
8-14\end{array}$ \\
\hline
\end{tabular}

Cases 1 and 2 were tested on two separate occasions.

Table 5 Neutrophil function (1978)

\begin{tabular}{|c|c|c|c|c|}
\hline Cases & Chemotaxis $(\mathrm{mm} / 3 \mathrm{~h})$ & $\begin{array}{l}\text { Quantitative iodination } \\
\left.\text { (pmols } / 10^{7} \text { cells } / \text { hour }\right)\end{array}$ & $\begin{array}{l}\text { Bactericidal capacity } \\
(\% \text { killed in } 2 \text { hours })\end{array}$ & $\begin{array}{l}\text { Fungicidal capacity } \\
(\% \text { killed in } 4 \text { hours) }\end{array}$ \\
\hline $\begin{array}{l}1 \\
2 \\
3\end{array}$ & $\begin{array}{l}0.85 \\
0.64 \\
2 \cdot 60 \\
\text { NT } \\
1 \cdot 60\end{array}$ & $\begin{array}{l}6 \cdot 5 \\
4 \cdot 8 \\
4 \cdot 0 \\
5 \cdot 5 \\
3 \cdot 4\end{array}$ & $\begin{array}{l}92 \\
\text { NT } \\
95 \\
93 \\
94\end{array}$ & $\begin{array}{l}\text { NT } \\
\text { NT } \\
88 \\
\text { NT } \\
84\end{array}$ \\
\hline $\begin{array}{l}\text { Controls }(n=22) \\
\text { Mean } \pm \text { SD } \\
\text { Range }\end{array}$ & $\begin{array}{l}1.85 \pm 0.29 \\
1.43=2.37\end{array}$ & $\begin{array}{l}5.0 \pm 1.5 \\
3.2-7.9\end{array}$ & $\begin{array}{l}89 \pm 4 \\
81 \pm 99\end{array}$ & $\begin{array}{l}89 \pm 4 \\
82-97\end{array}$ \\
\hline
\end{tabular}

NT $=$ not tested 
polio vaccine, as judged by the negative antibody titres to poliovirus types 2 and 3. Case 2 had raised serum IgM and IgE levels and low T-cell numbers. Case 3 was found to have raised IgM and IgE levels.

\section{Discussion}

The aetiology of this devastating and mysterious syndrome described by Hopkins is unknown. In our cases, the condition most closely resembles poliomyelitis, with the presence of acute lower motor neurone weakness of an anterior horn cell type of distribution, without any sensory loss, in association with inflammatory changes in the CSF, and severe permanent residual wasting and disability. No electrophysiological evidence of a peripheral neuropathy was obtained in our patients. In Case 2 there were clinical features - such as, limb pains, tender peripheral nerves, and limitation of straight leg raising - to suggest the possibility of inflammation of nerve roots, plexuses, and peripheral nerves. However, the permanent severe residual weakness, with fasciculation, suggests an associated anterior horn cell pathology. Consistent evidence of intercurrent viral infection has not been obtained, despite extensive search. All recorded cases of Hopkins's syndrome had previously been fully immunised against poliomyelitis. It was the observation of the reported association between the occurrence of paralytic poliomyelitis after polio immunisation in immunodeficient subjects which led us to investigate the immunological status of these patients. The patients were studied 3 to 5 years after their illnesses at a time when they were clinically well and not receiving systemic medications such as corticosteroids. The immunological abnormalities in our patients do not fall into the classical categories of immunodeficiency. The finding of low T-cell numbers indicates some impairment of cell-mediated immunity, such as occurs in the DiGeorge syndrome, ${ }^{22}$ which has been seen in association with paralytic poliomyelitis by one of us (J I M). However, the T-cell abnormalities in our patients were not severe, because mitogenic responses were not affected. Although raised IgM levels may represent a response to recent infection, our patients had not had any recent overt infections at the time of study in 1978. In the syndrome of immunodeficiency with raised $\operatorname{IgM},{ }^{16}$ this increase is probably a compensatory mechanism for $\operatorname{IgG}$ and $\operatorname{IgA}$ deficiency. It is of interest, in this respect, that serum $\operatorname{IgG}$ and $\operatorname{IgA}$ levels were slightly depressed in Case 1 at the time of the acute asthma attack. However, at follow-up all 3 patients had normal IgG and IgA levels. None the less, the raised IgM level in our patients may still represent a compensatory mechanism, but for underlying defects different from those described by Fudenberg et al. ${ }^{16}$ All 3 patients had raised IgE levels, but this was not unexpected, as this is often the case in allergic subjects. Of some interest was the detection of impaired neutrophil chemotaxis in Case 1. The serum IgE was markedly raised in this patient $(3550 \mathrm{IU} / \mathrm{ml})$ at the time of the paralytic illness, and was still moderately so $(1546 \mathrm{IU} / \mathrm{ml})$, subsequently. The findings in this patient therefore, bear some resemblance to the syndrome of raised $\operatorname{IgE}$ and defective neutrophil chemotaxis. ${ }^{17}$

We wish to introduce the hypothesis that patients who develop an acute poliomyelitis-like illness after an acute asthma attack, do so because of an underlying immunological deficiency, albeit of a minor nature. It is possible that further immunosuppression occurs in these patients at the time of an acute asthma attack as a result of stress, intercurrent infection, or corticosteroid therapy. This possibility is suggested by the observation in Case 1 of transiently reduced levels of $\operatorname{IgG}$ and $\operatorname{IgA}$ at the time of the acute attack. This patient also had a pronounced transient lymphopenia at that time. It is also worth noting, in passing, that Case 1 , who had the greatest degree of immunodeficiency, had the most severe muscular paralysis.

It may be that the host resistance is reduced to such a level that a virus, not usually considered pathogenic, may invade the anterior horn cells. Such a virus may be an opportunistic invader from the alimentary tract, or may even be a latent virus residing within the host, as can occur with the chronic infection that may follow the vaccination of the immunodeficient subject with live polio vaccine, in which case there may be a latent interval of several months before overt paralytic poliomyelitis develops. ${ }^{8} \mathrm{~A}$ parallel observation has also been made that herpes simplex virus may remain latent in sensory ganglia, and be reactivated as a result of experimentally induced immunosuppression. ${ }^{18}$

In our patients, only in Case 1 was a virus isolated at the time of the acute illness. This was a varicella virus, isolated from the throat. In Hopkins's 10 cases, one had adenovirus type 3, and another had echovirus type 18, isolated from the stool. In Case 2, a high serum titre of antibody to Cocksackie type B1 virus was observed soon after the illness. This finding would have been compatible with recent Cocksackie type B1 infection, but cannot be considered confirmatory. Infections with echovirus and Cocksackie virus have been associated with poliomyelitis-like illness in the past. ${ }^{19}$

The isolation of a varicella virus from the throat of Case 1 was a puzzling finding. The child had no overt evidence of clinical chickenpox infection at the time. We are aware of only one case (based on 
personal experience) of chickenpox associated with poliomyelitis-like illness in an infant. However, the herpes varicella virus has been reported on several occasions as causing anterior horn cell infection, with resultant paralysis, in the syndrome of herpes zoster. ${ }^{20}$ No zoster skin lesions were observed in our patient, but the possibility of anterior horn cell invasion by the varicella-zoster virus, without accompanying cutaneous zoster, has not been excluded. The failure to isolate a virus consistently from the other cases of Hopkins's syndrome so far described may possibly be due to the limitations of viral isolation techniques. Also, if the illness was due to reactivation of latent virus infection within the host, the virus may not be found in conventional sites, such as the alimentary tract. Moreover, viral serological studies may not be helpful if an immunological disorder results in poor antibody production. This may be applicable to Case 1 , who has failed to develop adequate polio antibody response, despite a full course of Sabin immunisation.

Further study of such cases is clearly required. No morbid anatomical data are available at present. Detailed immunological and virological studies of other patients with this rare syndrome will be required to test our hypothesis further.

We thank Dr T H Beare and Professor G M Maxwell for their co-operation, Dr David Hansman and Professor B P Marmion for help with the microbiological aspects of these cases, Dr Andrew Black and Dr John Fewings for performing some of the electrophysiological studies, and the Department of Photography, Adelaide Children's Hospital, for supplying the illustrations.

\section{References}

1 Hopkins I J, Shield L K. Letter: Poliomyelitis-like illness associated with asthma in childhood. Lancet 1974; 1: 760.

2 Hopkins I J. A new syndrome: poliomyelitis-like illness associated with acute asthma in childhood. Aust Paediatr $J 1974 ; 10: 273-6$.

3 Danta G. Electrophysiological study of amyotrophy associated with acute asthma (asthmatic amyotrophy). $J$ Neurol Neurosurg Psychiatry 1975; 38: 1016-21.

4 Ilett S J, Pugh R J, Smithells R W. Poliomyelitis-like illness after acute asthma. Arch Dis Child 1977; 52: 738-40.

5 Shapiro G G, Chapman J T, Pierson W E, Bierman C W. Poliomyelitis-like illness after acute asthma. $J$ Pediatr 1979; 94: 767-8.

6 Khan A, Sellars W A, Pfianzer J, Hill J M, Thometz D, Haenke J. Asthma and T-cell immunodeficiency: improvement with transfer factor and immunopeptide 1. Ann Allergy 1976; 37: 267-74.

7 Burgio G R, Nespoli L, Ugazio A G. Atopy as a minimal immunodeficiency. Eur J Pediatr 1978; 129: 221-9.

8 Wright P F, Hatch M H, Kasselberg A G, Lowry S P, Wadlington W B, Karzon D T. Vaccine-associated poliomyelitis in a child with sex-linked agammaglobulinemia. J Pediatr 1977; 91 : 408-12.

9 Mayer M M. In: Kabat E R, Mayer M M, eds. Complement and complement fixation in experimental immunochemistry. 2nd ed. Springfield, Illinois: Thomas, 1961: 133-6.

10 Ferrante A, Thong Y H. A rapid one-step procedure for purification of mononuclear and polymorphonuclear leukocytes from human blood using a modification of the Hypaque-Ficoll technique. J Immunol Methods 1978; 24: 389-93.

11 Scheinberg M, Blacklow N R, Goldstein A L, Parrino T A, Rose G B, Cathcart E S. Influenza-response of T-cell lymphopenia to thymosin. $N$ Engl J Med 1976; 294: 1208-11.

12 Alexander E L, Sanders S K. F $\left(\mathrm{ab}^{\prime}\right)_{2}$ reagents are not required if goat rather than rabbit antibodies are used to detect human surface immunoglobulins. J Immunol 1977; 119: $1084-8$.

13 Thong Y H, Ferrante A. A semi-automated microassay for quantitative leukocyte iodination. J Immunol Methods 1978; 20: 297-9.

14 Thong Y H, Ferrante A, Ness D. Neutrophil phagocytic and bactericidal dysfunction induced by bilirubin. Aust Paediatr J 1977; 13: 287-9.

15 Thong Y H, Ferrante A. Phagocytosis and killing of Torulopsis glabrata by human neutrophils. IRCS J Med Sci 1977; 5: 482.

16 Fudenberg H, Good R A, Goodman H C, et al. Primary immunodeficiencies. Report of a World Health Organisation committee. Pediatrics 1971; 47: 927-46.

17 Buckley R H, Wray B B, Belmaker E Z. Extreme hyperimmunoglobulinemia $E$ and undue susceptibility to infection. Pediatrics 1972; 49: 59-70.

18 Openshaw H, Wohlenburg C R, Seikizawa T, Asher L V, Notkins A L. Reactivation of latent herpes simplex virus (HSV) in mice by skin trauma and immunosuppressive agents (abstract). Neurology 1979; 29: 555.

19 Horstmann D. Enterovirus infections of the central nervous system; the present and future of poliomyelitis. Med Clin North Am 1967; 51 : 681-92.

20 Gupta S K, Helal B H, Kiely P. The prognosis in zoster paralysis. J Bone Joint Surg (Br) 1969; 51 : 593-603.

21 Thong Y H, Douglas B S, Ferrante A. Abnormal neutrophil chemotaxis in a syndrome of unusual facies, proportionate small stature, and sensorineural deafnessmutism. Acta Paediatr Scand 1978; 67: 383-7.

22 Thong Y H, Robertson E F, Rischbeith H G, et al. Successful restoration of immunity in the $\mathrm{Di}$ George syndrome with fetal thymic epithelial transplant. Arch Dis Child 1978; 53: 580-4.

23 Ammann A J, Hong R. Selective IgA deficiency-presentation of 30 cases and a review of the literature. Medicine (Baltimore) 1971; 50: 223-36.

24 Thong Y H, Steele R W, Vincent M M, Hensen S A, Bellanti J A. Impaired in vitro cell-mediated immunity to rubella virus during pregnancy. $N$ Engl $J$ Med 1973; 289: 604-6.

Correspondence to Dr J I Manson, Department of Neurology, Adelaide Children's Hospital, North Adelaide, South Australia 5006.

Received 11 September 1979

Editors' note: See Short Report on page 61. 